\title{
Mongolia and the Dilemmas of Deepening Eurasian Continentalism
}

\author{
Dr. Alicia Campi
}

\author{
President, The Mongolia Society
}

\begin{abstract}
Mongolia is geographically in the heart of the Asian continent. In the 20th century it was part of the geopolitical "Great Game" among Russia, China, and Japan. In the 21 st century, the pull of energy and mineral resource economics has changed the circumstances of the Eurasian continental paradigm and could provide the opportunity for this landlocked, Inner Asian country to find economic success, strengthen its national identity, and raise its global image. This paper will examine Mongolian reaction to the various Silk Roadinfluenced policies of its neighbors as it struggles not to be ignored in the emerging continental dynamism.
\end{abstract}

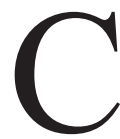

hina's efforts to re-invent the Silk Road trading route for the modern era, connecting Asia to the Middle East and Europe, has implications for the foreign policy options of all its neighbors. Mongolia, a democratic, free market society to its north, is one such nation that is shifting its economic and political strategies, in hopes of benefiting from the new opportunities that may appear in the next decade. Mongolian political and economic strategists see their nation, region, and continent as at a critical juncture which stimulates openness to institution-building to reduce tensions and the rise of regional networks to overcome energy and transportation challenges. From the 'critical juncture' theory perspective, the major factors of changing geostrategic context, political leadership, and crises, real or perceived are all present, ${ }^{1}$ and certainly Mongolia and its political leadership have been reacting to these circumstances.

While Chairman of the Mongolian Development Research Center, Dr.

For more on the theory of 'critical junctures' and its application to Northeast Asia see Kent Calder and Min Ye, The Making of Northeast Asia (Stanford, CA: Stanford University Press, 2010), 38-53.

This article is published under the Creative Commons CC-BY-ND License (http://creativecommons.org/licenses/by-nd/4.0/). This license permits use, distribution and reproduction, commercial and non-commercial, provided that the original work is properly cited and is not changed anyway. 
Ts. Batbayar's own research more than 15 years ago utilized development economics to offer formulations for a long-term development concept for Mongolia based on a comprehensive approach which took into consideration geography, culture, tradition, nomadic lifestyle, and current economic conditions. As editor, he brought together scholars and specialists to explore the nexus between potential Mongolian development patterns and foreign policy strategy in his comprehensive book, Renovation of Mongolia on the Eve of the XXI Century and Future Development Patterns (2000). In this volume it was correctly predicted that the $21^{\text {st }}$ century for Mongolia would involve increasing economic cooperation and interlinkage among the Northeast Asian and Central Asian nations and suggested that Mongolia could "play a bridging role inbetween Asia and Europe, and Central Asia and North East Asia."2

Mongolia at the end of the socialist era in 1989 had an economy with three distinct sectors: industrial and mining with the main national income source being the giant Erdenet copper mine; collectivized agriculture which included animal husbandry; and tourism. The Soviets during that period had to subsidize about one-third of Mongolia's budget. Nearly three decades later, the same three major sectors are still promoted as the most important economic drivers of the Mongolian economy. State-owned industries may have collapsed and the proportion of private mining operations funded all or partially by FDI greatly expanded, but mining-related revenues and taxes still provide the largest income to the state budget that continues to operate with great shortfalls. These deficits were sustained in the 1990s by foreign donor assistance and increasingly in the $21^{\text {st }}$ century by assuming large amounts of debt from foreign lenders. Calls for Mongolia to diversify its economy and rebalance away from the profitable, but more environmentally damaging mining sector, which alone has the potential to fund new domestic infrastructure, finance better health and social welfare systems, and pay down the foreign loans, may not be realistic options for the Mongolian population.

Mongolia has become active in North-South Korean issues, northern corridor transit routes, border free trade zones, and international peacekeeping operations. A major part of Mongolia's soft power foreign relations strategy is to see where it can find space to establish new regional institutional frameworks to promote continental transportation and communication formulas that can be mutually beneficial to all of the parties, so Mongolia is seen as more than merely a buffer nation. Mongolia's revised National Security Concept of 2010 stated the nation would give greater attention to the Asia-Pacific region,

L. Nyamtseren, Chapter 6, in Ts. Batbayar, ed., Renovation of Mongolia on the Eve of the XXI Century and Future Development Patterns (Ulaanbaatar: Mongolian Development Research Center, March 2000), 127-128. 
especially Northeast and Central Asia, and "Mongolia shall take an active part in the process of initiating dialogues and negotiations on the issues of strengthening regional security and creating a collective security mechanism." Thus, the country is seeking to strengthen its position in Asia and secure constructive participation in the political and economic integration process in the region. The manifestation of Mongolia's interest in establishing its own regional security mechanism that has attracted international attention is its "Ulaanbaatar Dialogue on Northeast Asian Security" (UBD), which is holding its $4^{\text {th }}$ iteration in June $2017 .{ }^{4}$ The UBD mechanism is a Track 1.5 forum annual meeting in Ulaanbaatar every June since 2014 to discuss Northeast Asian regional framework security strategies and the role of economic and environmental factors in promoting NEA regional cooperation and confidence.

Mongolia's overall goal has been the promotion of such new and revived institutional structures for Eurasia and its regional partners in order "to strengthen its position in the Asian region, to intensify bilateral relationships with other regional countries, to engage to a dialogue on political, security and economic cooperation of the region and to participate in the regional integration processes." It has chosen both to work through existing mechanisms such as United Nations (UN) multilateral organizations, international movements including Davos-organized economic summits and Council for Community of Democracies, and, increasingly, is willing to create its own regional structures to tackle long-standing disputes and bottlenecks.

\section{Mongolian Foreign Policy Strategies}

Mongolian policymakers, faced with the challenge of decades of isolation from the economic development of most of their Asian neighbors, expected that their nation, after making the necessary economic reforms, would be able to benefit in the 1990s from integration into the booming Asian regional market and the rest of the developed world. However, they insisted that maintaining national political security was of paramount importance and so recognized

\footnotetext{
National Security Concept 2012, Section 12 (c).

Frustrated because Mongolia had been shut out of the Six Party talks which have been dormant since 2009 and out of conviction that there needs to be progress on North-South Korean peninsula issues in order to improve Eurasian, Northeast Asian, and Mongolia's security, the Mongols created UBD, which they compare to the Helsinki dialogue of Cold War days. President Elbegdorj has proclaimed the Dialogue's goal was to assist and facilitate to peaceful solution of the confrontation on the Korean peninsula, so "Mongolia is willing to open up new gateways for the issues at standstill." This forum has attracted the participation of North Korean diplomat/researchers as well as those from the Six Party countries, India, and Europe. mongolianembassy.us website, "Foreign Policy."
} 
that abandonment of traditional reliance on one of the two border nations for protection was a new and potentially dangerous stratagem. Therefore, Mongolia developed a foreign policy concept called searching for special friends, labeled "Third Neighbors." This overarching strategy was proposed first by U.S. Secretary of State James Baker in August 1990, as a way for Mongolia to balance the tendency of China and Russia to vie over establishing control over Mongolia's international and domestic politics and economy. It has guided Mongolian foreign policy for more than 20 years, and is based on the idea of more equal balancing of its relations with its two border neighbors, Russia and China, while concurrently reaching out to other democracies, including the U.S., Japan, the European Community, and South Korea, for political and economic support. Mongolian policymakers sought a balanced, but not necessarily equidistant, relationship with the two neighbors, and declared the nation a Nuclear Free Zone. ${ }^{7}$ However, over the years Mongolian policymakers have adjusted the content of the "Third Neighbor" policy to reflect the realities faced.

One of the major factors in the past ten years impacting Mongolia has been its emergence on the Eurasian scene as a rapidly growing mineral-based economy heavily dependent on foreign direct investment (FDI). In response the Mongols have formulated a foreign economic policy, which I call Mongolia's "Wolf Strategy," that can be understood as Mongolia's version of "resource nationalism.' Mongolian policymakers of all political persuasions in the democratic era have been motivated by the belief that the nation's landlocked geography was the major decisive factor in shaping the country's destiny. Thus, Mongolia made integrating into the Asia-Pacific region a priority, considered its civilization and national identity as undeniably Northeast Asian, ${ }^{8}$ and flexibly re-imagined the nation as bridge for Northeast Asia into the continental heartland and on to the Middle East and Europe. It understands that NEA's economic growth requires secure energy resources, and the rise of China and its westward looking cross-continental strategy were trends which it could be useful only if Mongolia became more engaged in continental economic development. Mongolia saw its own abundant mineral deposits, which include oil, natural gas, and uranium, as the motivation for other NEA regional players to implement an Eurasian 'Infrastructure Linkage Strategy' that would permit Mongolia to build up its poor rail and pipeline freight transportation options to

\footnotetext{
Incorporated in Mongolia's National Security Concepts of 1994 and 2010.

Proclaimed by President P. Ochirbat to the $47^{\text {th }}$ session of the United Nations General Assembly on September 25, 1992.

8 AdiyagiinTuvshintugs, "The Role of the Small State in International Relations: Mongolian Perspective," paper presented to "Asia-Pacific security situation," December 3-5, 2002, Mongolian External Security Environment After Cold War (Selected works), National Intelligence Academy, Ulaanbaatar, 2012, 50.
} 
become a transit corridor.

During the resource boom in 2009-2013, the Mongolian economy had several years of double digit growth which was intimately tied to China's booming economy and high mineral commodity prices. Mongolia put the vast majority of its hopes on leveraging its vast minerals resources with huge FDI inflows to achieve quick socioeconomic growth and willingly mortgaged the nation's future to western and Chinese investors. The development of the huge copper-gold deposit of Oyu Tolgoi (OT) and coal-uranium deposit of Tavan Tolgoi (TT) led to a $17.3 \%$ growth rate in 2011 and $12.3 \%$ in 2012 . In an allusion to the successful Asian Tigers of the $1980 \mathrm{~s},{ }^{9}$ Mongolia was labeled the 'Asian Wolf' and its mineral-based economy, the "wolf economy." Financial blogs spoke of a mining mania, and the Mongolian government itself promoted the idea of foreign mining countries lining up to sign lucrative deals worth $\$ 25$ billion in investment. ${ }^{10}$ However, by the middle of the second decade of the $21^{\text {st }}$ century, the mining expansion had collapsed and the growth rate fallen precipitously to $1 \%$ in 2016 . This has been driven by falling commodity prices, domestic corruption and incompetence, and an element of conscious Mongolian foreign policy decision making to slow foreign investment.

Mongolian policymakers and politicians of all political persuasions wanted to modify the foreign investor climate of the first decade of democracy, because they saw it as failing to prevent the monopolization of the economy by one of its two border neighbors. The Soviet monopoly of communist times was replaced by that of the Chinese, and this simply was not acceptable or sustainable for Mongolia. Mongols blamed the western financial experts and multilateral organizations that pushed the country to seek economic development regardless of how it could hurt the country's sovereignty and national identity, and for institutionalizing policies that promoted Chinese interests at Mongolia's expense. Many Mongolians also have come to believe that development of their vast mining resources has not yet resulted in promised broad-based, inclusive growth and benefits to the population. Rather, it has led to corruption within governmental and mining circles, and foreign, specifically Chinese, control over trade and economic relations.

During the last several years Mongolia has seen its international reputation among foreign investors plummet. The constant drumbeat of criticism by westerner observers about Mongolian corrupt practices increased the cynicism within Mongolian society and tempered its respect for free markets. ${ }^{11}$ As

Singapore, Taiwan, ROK, and Hong Kong.

10 Jaime FlorCruz, "Mining fuels Mongolia's 'wolf economy"” (May 20, 2011), http://www.cnn. com/2011/WORLD/asiapcf/05/19/mongolia.mining.economy/index.html.

11 Many western economists inflamed these pessimistic views by warning of the so-called "resource curse" or Dutch disease wherein quick riches not properly managed are dissipated in 
a result, in the last few years Mongolian leaders embarked upon their own "Asian Wolf Strategy" based on a kind of resource nationalism with national security objectives to modify the unregulated democratic, free market structures of the first years of democracy, even when such actions caused FDI to dry up. Investment laws were changed so that the government might retain control over the development and management of its largest mineral deposits instead of proceeding with privatization divestiture.

\section{Mongolia Embraces Globalization and Continentalism}

During the $21^{\text {st }}$ century expansion of Chinese influence in the Eurasian region, there has been a parallel effort in Mongolia, particularly in the 8-year presidency of Tsakhia Elbegdorj, which ends June 2017, to heighten Mongolia's international image and global presence. One cannot just explain this as a Mongolian reaction to China's rise in regional influence or as the result of a retrenchment period stimulated by the boom-bust nature of the mineral economy. Rather, it should be evaluated more generally within the context of Eurasian continentalism, ${ }^{12}$ that is exemplified by various multilateral, integrative, economic and transportation strategies, often labeled 'Silk Road' initiatives, which have been promulgated by different Asian countries in the last few years. Examples of these strategies include the 1997 Japanese Eurasian Diplomacy, ${ }^{13}$ the 'Eurasia Initiative' of South Korean President Geun-hye in October 2013, ${ }^{14}$ and Russia's Eurasian Economic Union of 2015. ${ }^{15}$

corruption, mismanagement, and income inequality.

12 Enunciated in Kent E. Calder, The New Continentalism: Energy and Twenty-First-Century Eurasian Geopolitics (Yale University Press, 2012).

13 In July 1997 Japanese Prime Minister Hashimoto Ryutaro introduced the concept of Eurasian Diplomacy as a pillar of Japan's foreign policy which would encompass Russia, China as well as the Newly Independent States in the Central Asian Caucasus region. The idea is that Japan should play an active and leading role to help the countries foster political and economic stability. Christopher Len, Uyama Tomohiko, and Hirose Tetsuya, Japan's Silk Road Diplomacy Paving the Road Ahead, Central Asia-Caucasus Institute \& Silk Road Studies Program (SAIS Johns Hopkins University, 2008), 7.

14 This 'Eurasian Initiative' is a proposal to link rail and road networks, energy, and logistics infrastructure from Korea's Busan across the Eurasian continent to Europe in a modern 'Silk Road Express.' Park asserted that 'to combine South Korea's policy of strengthening Eurasian cooperation and Russia's policy of highly regarding the Asia-Pacific region to realize our mutual potential at the maximum level and move relations between the two countries forward. .. .South Korea and Russia will join hands to build a new Eurasian era for the future." Chang Jae-soon, “(3rd LD) S. Korea to participate in Russian-led rail, port development project in N. Korea," Yonhap (Seoul: November 13, 2013), english.yonhapnews.co.kr.

15 Created in 2015 by Russia, Kazakhstan, Kyrgyzstan, Belarus and Armenia, the EEU claims to be the first successful post-Soviet initiative to overcome trade barriers and promote 
Mongolia has embraced a greater role in promoting its own vision of Eurasian continentalist synergy and in extending its global participation. Mongolian policymakers have recalibrated their situation to determine what unilateral foreign policy actions can be utilized to enhance the country's international image making. Thus, during this decade Mongolia has sought to integrate into the Eurasian market and raise its regional and global profile. Out of frustration with the status quo of big power dominance in its neighborhood which severely limits its trading partners and economic development options, it has embarked on a much more activist foreign policy that utilizes 'soft power' mechanisms and embraces political and economic continentalist integrative trends to promote itself.

\section{Re-interpreting "Third Neighbor" Policy}

One major action taken was to revise its "Third Neighbor" Policy. While still considered the basic principle of Mongolia's foreign relations and national security policy in the democratic era, it had failed to prevent Chinese monopoly over the economy and did not generate the western, particularly U.S., Japanese, and German, FDI that was expected. As a result Mongolia expanded its "third neighbor" definition to a more Eurasian focus to emphasize India, Turkey, Persian Gulf nations, Vietnam, and even Iran in order to diversify trade partners for its minerals and find new sources of energy and consumer goods.

Some of these nations seek partnership with Mongolia because of their own Eurasian continentalist perspectives. From a political-strategic perspective, India and Mongolia share a common concern about Chinese hegemony in the region, which explains why Mongolia's attachment to India from the communist era has only deepened in the last few years. ${ }^{16}$ India can act as an economic partner for Mongolia, and it is in India's interest not to secede upper Eurasia to China. A central component in the Indian-Mongolian strategic partnership is that India is the world's largest democracy and Mongolia is the only democracy in its neighborhood. During the state visit of Indian Prime Minister Shri Narendra Modi from May 16-18, 2015, Modi and Mongolian Prime Minister Chimed Saikhanbileg signed a new strategic partnership agreement and

integration on the Eurasian continent. See The Eurasian Economic Union: Power, Politics and Trade,Europe \& Central Asia, Report No. 240 (July 20, 2016), https://www.crisisgroup.org/ europe-central-asia/central-asia/eurasian-economic-union-power-politics-and-trade.

16 In 1959 Mongolian Premier Yumjaag Tsedenbal went to Delhi and former Prime Minister Indira Gandhi traveled to Ulaanbaatar in 1965. Since then, two Indian presidents, Ramaswamy Venkataraman in 1988 and Pratibha Patil in 2011, have visited Mongolia. On the Mongolian side, presidents visiting India included Punsalmaag Ochirbat in 1994 (who signed the Treaty of Friendly Relations and Cooperation), Bagabandi in 2001, and Elbegdorj in 2009. 
renewed their Treaty of Friendly Relations and Cooperation. India extended Mongolia a \$1 billion credit line for infrastructure development and expansion of Mongolia's railway system. Both sides agreed to deepen defense cooperation and intensify civil nuclear cooperation, and strengthen trade through agreements on shipping and logistics, highways, electric power, energy, dairy, and taxation. ${ }^{17}$

Another country that has its own agenda for dealing with Mongolia is Iran. Since the collapse of communism in the Soviet Union, Iran has aspired to developing closer relations with the entire Eurasian continent. Its calculus involves utilizing identity politics in Mongolia's western provinces, which are peopled by adherents of Islam. Iran and Mongolia trace their modern political relationship to 1971 when diplomatic relations were first established between the Shah's Government and then communist Mongolia. Since 1990, the economic relationship has been relatively minor for both countries, although there were consultations on petroleum development. For the last 20 years Hazara ${ }^{18}$ Mongol populations in Iran have appealed for Mongolian sanctuary and support to prevent Iranian forced repatriation to Afghanistan. Mongolia responds cautiously on this issue, because it sees benefit to expanding ties to Iran as a partial counterweight to China's economic monopolization.

The nature of the Mongol-Iranian relationship was remade during the Elbegdorj presidency. The basics of the new relations today are meat and uranium. In early December 2010 a new Mongolian-Iranian joint venture entitled Bayan Meat, Ltd., signed a sheep meat export contract with Mongolia's largest meat slaughterhouse, Mahimpex of Ulaanbaatar. ${ }^{19}$ That same year it was announced that Iran had been exploring its options for Mongolian raw uranium. The major turning point in bilateral relations came in September 2012, when Iran permitted President Elbegdorj to tour one of its nuclear facilities after he had participated in the $16^{\text {th }}$ Summit of the Non-Aligned Movement in Tehran. He was the only foreign leader allowed to visit Iran's main uranium enrichment

17 India and Mongolia signed 13 agreements to further strengthen bilateral ties on enhancing cooperation in border guarding, policing and surveillance, air services, cyber security (Cyber Security Training Centre for the Mongolian Defense Ministry), and solar and wind renewable energy. The agreements cover economic relations, development partnership, defense and security, and people-to-people contacts. Miliate, "Modigolia? Indian-Mongolian Relations post-PM Modi’s Trip to Ulaanbaatar,” Mongolia Focus (May 18, 2015), http://blogs.ubc.ca/ mongolia/2015/modigolia-indian-mongolian-relations/.

18 Hazara are Shiite Turko-Mongols in Afghanistan who have been repressed by the Taliban and the Afghan majority Sunni population. Continuous war and brutalities resulted in Hazara migration to Iran as well as to Pakistan; however, Hazaras in Iran accuse the Iranians of maltreatment.

19 The President of Mongolia's Meat Association, M. Lhachinbaltai, montsame.news.mn, (November 13, 2010). 
plant in the Iranian town of Natanz..$^{20}$ In 2015 the Iranian President met with President Elbegdorj on the sidelines of the SCO Summit and later declared that "Iranian companies are ready to cooperate with Mongolia energy, road construction and mining sectors." ${ }^{21}$ Whether it is meat or uranium, the growth in relations between Mongolia and Iran should continue throughout this decade because both are seeking new trade partners and participation in several regional cooperation and collective security organizations.

\section{Trilateralism}

Trilateralism is another major foreign relations strategy Mongolia recently adopted in response to the new Sino-Russian cooperative partnership developing on the Eurasian continent and motivated by Mongolia's overall trade predicament and limited options to find a way towards trade partner diversification. The Chinese 'One Belt One Road' (OBOR) concept attracted attention in Mongolian policymaking circles, mainly because Mongolia initially appeared to be ignored in the plan. Mongolian concern was intensified by the rapprochement since 2014 between Chinese President Xi Jinping and Russian President Vladimir Putin, which again seemed to exclude a role for Mongolia. Mongols understand that development of Sino-Russian energy ties is the most important factor today driving "strategic convergence" of China and Russia. ${ }^{22}$ This cooperative phenomenon reminds Mongolian policymakers of the times decades ago when the two neighbors made decisions about Mongolia's foreign and economic affairs without consulting the Mongols. As a result, Elbegdorj and many other Mongolian policymakers recognized that the Chinese-Russian political rapprochement could only profit Mongolia if Mongolia was seated at the negotiating table and participating in drafting new continental transport growth models.

Despite Mongolia holding separate successful bilateral summit meetings with Chinese and Russian leaders the summer of 2014 in Ulaanbaatar, ${ }^{23}$

\footnotetext{
20 "Iran opens nuclear site to Mongolia's president" (Tehran: September 3, 2012),

http://triblive.com/news/2532074-74/iran-nuclear-site-visit-elbegdorj-iranian-mongoliapresident-tehran-uranium.

21 "Iran ready to enhance economic ties with Mongolia" (August 30, 2015),

http://en.mehrnews.com/news.

${ }_{22}$ "Chinese perspectives on Russian oil and gas," Indra Overland and Kyrre Elvenes Braekhus, Russian Energy Power and Foreign Relations-Implications for Conflict and Cooperation, ed. JeronimPerovic, Robert W. Orttung, Andreas Wenger (London and NY: Routledge, CCS Studies in Security and International Relations, 2009), 214.

23 Mongolia signed with Chinese President Xi 26 agreements covering mining and finance deals, as well as a significant joint declaration upgrading their relationship to a "comprehensive strategic partnership." Both sides noted that two-way trade volume between China and
} 
Mongolia pushed for a new trilateral mechanism to make certain that these two powerful neighbors did not proceed with transportation and energy cooperation without considering the interests of Mongolia. President Elbegdorj determined that innovative thinking beyond the "Third Neighbor" policy was needed, and so he called for a 'trilateralism' policy focused on Mongolian, Russian, and Chinese transnational infrastructure development and economic cooperation via annual summit coordination among the presidents. It is highly likely that the impact of Mongolia's strengthening political-military relationship with the United States, as represented by the visit of U.S. Secretary of Defense Chuck Hagel to Ulaanbaatar on April 11, 2014, propelled Xi and Putin to favorably respond to Elbegdorj's proposal.

The first trilateral summit among the three presidents took place on the sidelines of the September 11-12, 2014 Shanghai Cooperation Organization (SCO) annual meeting in Dushanbe, Tajikistan. President Elbegdorj suggested all sides work together on specific projects related to transnational transit infrastructure development. ${ }^{24}$ The three countries agreed in principle to build a 'Steppe Road' in Mongolia, reviving a pre-modern transport network that facilitated trade between China and Russia, and incorporating the 'Steppe Road' into the Chinese OBOR and the Russian Eurasian Economic Union (EEU). President Xi responded that if this concept were to succeed, the three nations needed to strengthen traffic interconnectivity, facilitate cargo clearance and transportation, and build a transnational power grid. ${ }^{25}$ As for Putin, he noted that the geographic proximity of Mongolia, Russia and China facilitated long-term projects in infrastructure, energy and mining. ${ }^{26}$

Since that first tripartite summit, there have been two others. On July 9, 2015 Mongolian Elbegdorj met Xi and Putin at the second trilateral summit meeting in Ufa, Russia on the sidelines of the BRICS meeting and $15^{\text {th }}$

Mongolia had leaped from \$324 million in 2002 to nearly \$6 billion in 2013, accounting for more than half of Mongolia's total foreign trade, and they agreed to work to increase bilateral trade to $\$ 10$ billion by 2020 under a "three-in-one" cooperation model, integrating mineral exports, infrastructure construction, and financial cooperation. "Currency Swap Agreement," Shared Encyclopedia (August 21, 2014), http://www.et97.com/subview/2153822/2153822. $\mathrm{htm}$. Two weeks later, on September 3rd, Putin signed 14 bilateral agreements with the Mongols. In 2013 Russian-Mongolian trade volume had fallen to \$1.6 billion, with Mongolian exports to Russia reaching only $\$ 70$ million (representing $1.4 \%$ of total exports). "Russia's Putin in Mongolia for 5-hour visit," Associated Press (September 3, 2014).

24 With the exception of a tripartite meeting held almost a century ago at the level of vice foreign ministers. G. Purevsambuu, "First-ever summit held between Presidents of Mongolia, Russia, and China," The Mongol Messenger (September 19, 2014).

${ }_{25}$ Mongol Messenger (September 19, 2014); website of President of Mongolia (September 11, 2014).

26 Mongol Messenger (September 19, 2014). 
annual SCO summit. Elbegdorj promoted trilateral cooperation on railway transportation, logistics, facilitation of agricultural and mineral trade, infrastructure construction and other sectors. Xi responded by urging relevant government departments in the three countries "to step up the docking of development strategies of each countries and transform the vision into concrete cooperative projects. ${ }^{.7}$ At this meeting the three presidents approved a roadmap for trilateral cooperation and witnessed the signing of a memorandum on compiling a guideline for building the trilateral economic corridor, a framework agreement on facilitating trilateral trade, and a framework agreement on cooperation on ports of entry among the three countries.

The third tripartite summit on June 23, 2016, organized on the sidelines of the 16th SCO annual meeting in Uzbekistan's Tashkent, saw the emergence of the breakthrough agreement on establishing an economic corridor among the three countries. They signed an "Economic Corridor Plan" agreement the purpose of which is to coordinate specific plans to facilitate economic traffic among the countries, similar to the arrangements among member countries in the EU. The presidents also signed an agreement between Russia's Federal Customs Service, China's General Administration of Customs, and Mongolia's General Taxation and Customs Administration, which mutually recognizes custom control inspections of certain goods. ${ }^{28}$ Chinese President $\mathrm{Xi}$ expressed satisfaction with the momentum of trilateral cooperation: "We three sides should actively engage in the discussion of building cross-border economic cooperation zones, enhance industrial tie-in, boost sub-regional cooperation in our adjacent areas, and promote the common development of our adjacent areas." He urged building the economic corridor and strengthening cooperation in transportation infrastructure connectivity, port construction, industrial capacity, investment, trade and economy, cultural and people-topeople exchanges, and environmental protection - all in cooperation with the framework of the $\mathrm{SCO}^{29}$

On May 12, 2017 Mongolian Prime Minister Jargaltulga Erdenebat met with President Xi prior to the opening of the Beijing Leaders' Roundtable at the Belt and Road Summit for International Cooperation on May 14-15. The leaders supported the principle that coordination of Mongolia's Economic Corridor and Steppe Road (designed to boost the Mongolian economy through trans-border transportation) with OBOR would provide new opportunities for

\footnotetext{
27 "Xi assent to trilateral summit with Russia, Mongolia" (August 22, 2014), http://thebricspost. com/xi-assent-to-trilateral-summit-with-russia-mongolia/\#.WBy6EoWcF9A

28 Khaliun Chimeddorj, "Mongolia, Russia and China agree to establish economic corridor," $U B$ Post (June 27, 2016).

29 "China, Russia, Mongolia endorse development plan on economic corridor," Xinhua (June 24, 2016), http://english.cctv.com/2016/06/24/ARTIJkwoLdfFUjK7unWMv01N160624.shtml.
} 
Mongolia and China to intensify ties so that both sides could invigorate their comprehensive strategic partnership with concrete cooperation initiatives. ${ }^{30}$ In a veiled reference to Mongolia's democratic "third neighbors", Xi cited the adage that a 'close neighbor is better than a distant friend.' He noted that "Mongolia and China should aspire to stay together to benefit from global growth." ${ }^{31}$ In his speech themed 'Policy Coordination for Close Partnership', Mongolian Prime Minister Erdenebat mentioned Mongolia's initiative to forge a trilateral mechanism with its neighbors and desire to be an important participant in OBOR. He emphasized that Mongolia's ties with China remain a foreign policy priority, and indicated interest in developing joint projects in trade, economy, trans-boundary development and infrastructure.

Prime Minister J. Erdenebat and his counterpart, Li Keqiang, at that conference held official talks on intensification of trade and economic cooperation, environmental protection, and climate change. Erdenebat underlined that increasing exports of mining products, including iron ore and coal and agricultural and animal origin products, to China could play an important role in the economic revival of Mongolia. The two nations discussed cooperation on projects to produce liquid fuel and synthetic gas from coal at the Tavan Tolgoi mine, and collaborating in infrastructure and air pollution fields. The talks included the topic of the construction of a power plant at Shivee-Ovoo coal mine not far from the Mongolian capital and how to implement the Kherlen Gobi project, which could impact regional water resources. The Argun, Kherlen and Shilka rivers, which are located at the headwaters of the transboundary Amur-Heilong River basin, lie in the eastern part of the Dauria eco-region shared by Russia, China and Mongolia. Economic development and water use in the three countries have delayed the creation of an applicable transboundarymechanism to protect and sustainably utilize common water resources. For Mongolia, the Kherlen Gobi project would involve the installation of $540 \mathrm{~km}$ of pipelines with $50 \%$ of the water to be used for mining and industrial uses, $30 \%$ for irrigated croplands, and the remaining for households, livestock and environmental water usage. ${ }^{32}$ These plans are part of an overall strategy to

30 President Xi Jinping was quoted: "Many deals have been put into action since I visited Mongolia in 2014. In the future, Mongolia-China relations have to stand on a more concrete foundation." The Mongol Messenger, May 19, 2017.

31 "Prime Minister attends Belt and Road Summit in Beijing China to grant CNY 2 billion in aid in addition to a previous USD 1 billion loan," The Mongol Messenger, May 19, 2017.

32 There have been a few World Bank feasibility studies on responding to possible socioeconomic, financial and environmental questions on how to convey $1500 \mathrm{~L} / \mathrm{sec}$ water from Kherlen River to Shivee Ovoo, Sainshand, Samyn Uud and with a separate pipeline to Tsagaan Suvarga. "SOUTHERN GOBI REGION'S WATER SUPPLY ISSUES" (Ulaanbaatar, 2009),

http://siteresources.worldbank.org/INTMONGOLIA/Resources/Tsedenbaljir_Presentation.pdf. 
promote development of major Mongolian mining projects, such as Tavan Tolgoi, the Oyu Tolgoi concentrate plant, and transport railroads and energy supply stations.

The two Prime Ministers witnessed the signing of 21 bilateral cooperation documents, including coordinating Economic Corridor and OBOR initiatives, establishing a joint council of humanitarian exchange, strengthening trade, investment and economic ties, and developing a science park and innovation infrastructure. One of the agreements established a joint a study on possibilities to establish a Free Trade Agreement. There also were projects to build a Ulaanbaatar to Mandalgobi electric transmission line and substation with the funding of a Chinese US\$1 billion soft loan, reduce air pollution in Ulaanbaatar, establish a power purchase agreement, and cooperate in developing a steel factory. ${ }^{33}$

Many foreign observers saw Mongolia's push for trilateralism with China and Russia as a worrisome phenomenon. There was concern over China and Russia's deepening coordination with Mongolia and about President Tsakhiagiin Elbegdorj's real intentions in promoting trilateralism. Despite the strong democratic record of Elbegdorj from his days in the streets as one of the key protest leaders who brought down Mongolia's communist government, Mongolia's new strategy caught many, including in the restless foreign investor community, off guard. ${ }^{34}$ Originally, the United States government was not supportive of the concept of a Sino-Russian-Mongolian trilateral summit in 2014. This was a non-public position held not only by the U.S. but also by its close allies, especially Japan. ${ }^{35}$ In response to this unease, Mongolian foreign policy strategists called for the formalization of another form of trilateralism-among the United States, Japan, and Mongolia. One could argue that this informal trilateralism has existed since the early 1990s, when the U.S. encouraged and coordinated Japanese leadership in the donor assistance

33 Another project would involve building a $321 \mathrm{~m}$ long Bayanzurkh bridge and $289.4 \mathrm{~m}$ Sonsgolon concrete bridge over the Tuul River with the funding of a US\$ 500 million soft loan.

34 When a Mongolian delegation visited New York and Washington in connection with President Elbegdorj's speech to the United Nations General Assembly in late September 2014, its members were met with a barrage of questions from American officials about the future of Mongolian allegiance to its "third neighbor policy." Personally told to the author by a member of the Mongolian delegation.

35 U.S. authorities believed China might receive some special considerations in the Mongolian lucrative market for renewable and traditional power generation to the disadvantage of American companies. Japan was concerned about the fanfare and publicity in the region leading up to the 'celebration' of the $75^{\text {th }}$ anniversary of the joint Soviet-Mongolian victory over the Japanese army at Khalkhin Gol (Nomonhan) that could encourage the Chinese and Koreans to engage in a new round of 'Japan-bashing'. 
policies devised for Mongolia to make its transition to democracy and the free market. U.S.-Japanese coordination with Mongolia on the prioritization and funding of the transition changes was carried out very openly, and a pattern developed whereby the United States took the lead in organizing privatization and democracy-building institutions, while Japan became the prime mentor and guide for establishing the economic mechanisms, including banking, that were necessary for Mongolia's free market to function. As the years progressed, this informal cooperation morphed into an active policy of U.S.-Mongolian military cooperation paralleling but not competing with Mongol-Japanese joint investment in major domestic construction projects from hospitals to roads to airports and power stations.

Mongolian President Elbegdorj over his term of office developed a strong relationship with Japanese Prime Minister Shinzo Abe, so Elbegdorj encouraged the U.S. and Japan to act with Mongolia as a counterbalancing triangular relationship to the Sino-Russian-Mongolian trilateralism. However, the public reason given for the more organized and public coordination among the three democratic nations was centered on involving Mongolia in a positive way to approach North Korea. Representatives from the U.S., Japan, and Mongolia in September 2015 announced that trilateral foreign ministerial talks were being prepared in order "to tap into Mongolia's close ties with North Korea and settle a host of issues involving Pyongyang." ${ }^{36}$ The new trilateralism was justified as a non-threatening posture towards Mongolia's neighbors which included Mongolia in a multilateral framework, in hopes that Mongolia could play a role in helping to resume the stalled Six-Party talks on Pyongyang's nuclear program and making progress on the issue of North Korea's abductions of Japanese nationals during the 1970 s and 1980 s.

The inaugural trilateral meeting among Mongolia, the United States and Japan was held on September 29, 2015 in New York to discuss "some topics of deepening regional security cooperation and expanding economic relations." ${ }^{37}$ Mongolian Foreign Minister Lundeg Purevsuren, U.S. Assistant Secretary of State for the Bureau of East Asian and Pacific Affairs Daniel Russel, and Director General for the Asian and Oceanian Affairs Bureau of the Ministry of

\footnotetext{
36 The proposal to hold a foreign ministerial meeting among the three nations was agreed to in principle in 2013 by the leaders of Japan and Mongolia. "Japan, U.S., Mongolia mull first trilateral foreign ministerial talks," www.japantimes.co.jp (Kyodo: August 14, 2015). The North Korean topic was discussed when U.S. Secretary of State John Kerry held talks with Mongolian Foreign Minister Lundeg Purevsuren in mid-July in the United States and during Prime Minister Shinzo Abe's late July 2015 visit to Ulaanbaatar.

37 “AMBASSADOR TALKS TO THE MONGOLIAN OBSERVER” (June 1, 2016), http://mongolianembassy.us/2016/06/ambassador-talks-to-the-mongolian-observer/\#. WCZfrIWcF9A.
} 
Foreign Affairs of Japan Junichi Ihara met on the sidelines of the opening of the UNGA. Their joint statement addressed the significance of the new consultation mechanism in a trilateral format by explaining that the new framework "laid the foundation for an important dialogue mechanism with our Third neighbors the U.S and Japan - to exchange views on a broad range of regional and global security and economic issues, and on how to coordinate actions at the regional and global levels that reflect shared interest." ${ }^{38}$ Future U.S.-Japanese-Mongolian trilateral foreign ministerial meetings will be organized on the fringes of international conferences; however, it is unlikely that this trilateral relationship will receive the same degree of publicity as the Sino-Russian-Mongolian one.

The Sino-Russian-Mongolian Trilateral relationship should continue for the next decade, fueled by the necessity of the three countries for greater modern transport infrastructure construction so that each economy can continue to grow and trade. At the same time, such factors hold the potential to thwart Mongolia's economic rise. With peace in the greater Northeast Asian region in the post-Cold War period and particularly closer political relations between Russia and China, economic forces have risen to trump each nation's national security concerns. As long as this atmosphere between the two great Eurasian continental superpowers continues, Mongolia can utilize its trilateral policy for its benefit. If the relationship between China and Russia turns increasingly hostile and/or the huge sums of FDI required to build all the new connective infrastructure does not emerge because of a severe economic downturn in China or greater political instability on the Korean peninsula or between nations in the Sea of Japan and East China Sea, the trilateral policy will fall apart or not be effective. ${ }^{39}$

\section{Development of New Economic, Energy and Industrial Zones}

To maximize its economic and mineral resources, Mongolia in the future must increase the value of its abundant raw materials and sell them as processed products rather than only in raw form. One way to accomplish this is through developing industrial manufacturing zones. Mongolia's Parliament in 2007 approved the Law on Economic Zones, and two special economic areas were to be established in the city of Altanbulag on Russian-Mongolian border and Zamiin-Uud on Chinese-Mongolian border. Allocation for the Zamiin-Uud Foreign Economic Zone (FEZ) in the south is an area of 900 hectares. It was

\footnotetext{
38 "The first Mongolia-U.S.-Japan Trilateral Meeting was held in New York" (September 15, 2015), http://www.mnb.mn/i/64855.

39 "Answers to journalists' questions following a working visit to Mongolia," President of Russia website (September 3, 2014).
} 
to consist of three major sections - industrial, commercial, and tourism-service. In the Industrial section emphasis was placed on environmentally friendly industrial production, including assembling factories of foreign audio and video equipment, home appliances and electronic goods for export, and the production of textiles and clothing, furniture, and souvenirs. The Commercial section was to include warehouses, business, exhibition centers and commodity exchange, and parceling, bottling and packaging of goods, and banking, financial services, information and communication centers. In the third Tourism and Services section, the Mongols envisioned tourist camps, hotels, restaurants, cafes, fast food shops and entertainment, golf courses, horse racing, camel polo, and a controversial casino with the clientele being cross-border Chinese.

Although the legislation sought a virtually tax-free business environment and minimum bureaucratic obstacles for foreign and domestic companies, the southern border zone never moved beyond two controversial and compromised international tenders which eventually were rejected by the government. Although this zone theoretically still is a goal, the Elbegdorj government turned its attention in 2011 to creating an industrial park in the Gobi at Sainshand, 230 $\mathrm{km}$. to the north. Sainshand, a city of 20,000 people is an old caravan city not far from the two giant mineral complexes at Oyu Tolgoi and Tavan Tolgoi. It is envisioned as a site for coking coal plants, a copper smelter, electric, and other processing plants, and facilities to process food, make clothes, iron pellets and cement - all financed by public-private foreign and domestic investment and employing Mongol workers. The government approved a plan to sell to private developers $66 \%$ of the Sainshand Industrial Complex, worth about $\$ 4$ billion, to build infrastructure such as a power distribution network and a waste water facility. Potential investments in the park, designed by U.S. civil engineering company Bechtel Group Inc., may exceed $\$ 11$ billion. ${ }^{40}$ Feasibility studies have proceeded, but water problems were discovered which have delayed development.

The Altanbulag northern border zone, which was expected to be less lucrative, began operations slowly because the volume of Mongolian-Russian trade was small. Its size, adjacent to the Siberian Russian Khiagt border port $335 \mathrm{~km}$. north of Ulaanbaatar, is planned for 500 hectares with 15,000-20,000 inhabitants. Most of the export goods now are hauled by trucks, but the Mongols plan to develop it into a modern industrial site for international trade, import and export processing and warehousing. ${ }^{41}$ The official launch of the

\footnotetext{
40 Tsetsegsuren, "The struggles of the Sainshand Industrial Complex, Unuudur (December 2, 2014).

41 “Law on Economic Zones,” Invest Mongolia, May 11, 2007, https://investmongolia.wordpress. com/.
} 
Altanbulag FEZ took place on June 24, 2014 to serve as a direct link to Russian markets and out to the Pacific. At this point this zone is progressing well. In the first stage, construction materials and auto parts will be the focus of its trade center. Proposals to build a $25 \mathrm{~km}$. from Altanbulag FTZ to the closest railway station at Sukhbaatar City, a thermal power plant, residential areas, hotel complexes and recycling plants are under discussion. ${ }^{42}$

In October 2013 Mongolia agreed to establish a working group with China to oversee the construction of new road, rail and pipeline infrastructure connecting the two countries with Russia. The developing Mongolian-RussianChinese Northern Railway project, agreed to in June 2016, committed the countries to upgrading regional rail transport by modernizing existing capacity and building new routes. Landlocked Mongolia wants to find financing from China's AIIB to build $550 \mathrm{~km}$. (342 mi.) of new railways and plans to expand existing routes. It is believed that the Mongolian-Russian-Chinese Northern Railway project should provide the impetus for a trilateral transportation logistics company that will promote development of Altanbulag FEZ's railway transport capacity.

An indication that the Chinese believe that cooperating with the Mongols to create a stronger industrial base, which then can be linked to the OBOR network, is the willingness of the Chinese government to invest in a variety of additional infrastructure projects. In 2017 the Chinese concluded an agreement with the Mongolian Ministry of Education, Culture, Science and Sports on development of science incubator center and technology park. ${ }^{43}$ Chinese Energy Investment Corporation established a concession agreement in 2017 with Mongol Power LLC, founded by the U.S. Firebird Management company, to implement a power plant project in Tevshiin Gobi. ${ }^{44}$ It involves building a 600 MWt power plant at the Tevshiin Gobi coal mine, located in the eastern Gobi. The $\$ 1.1$ billion project aims to ensure energy stability of the central energy network and supplement the region's energy deficiency now being supplied by China. ${ }^{45}$

42 M. Zoljargal, "Altanbulag free trade zone to improve cross border trade," UB Post, June 19, 2014. http://ubpost.mongolnews.mn/?p=9949.

43 With Ministry of Science and Technology of China, "Technology transfer center to be established based on innovation development" (May 17, 2017), http://montsame.mn/en/ $\mathrm{read} / 10091$.

44 "Mogul - Tevshiin Gobi Power Plant 600 MW - Dundgovi Province Project Overview," https://www.construction-ic.com/HomePage/Projects?.

45 USA and other Mongolian investors will fund the project with a ratio of 51:49. 600MWt power plant to be built in Dundgobi aimag. B. Ooluun, "Large-scale projects to be implemented in coming years in collaboration with China" (May 17, 2017), http://montsame. $\mathrm{mn} / \mathrm{en} / \mathrm{s} /$ largescale-projects-to-be-implemented-in-coming-years-in-collaboration-withchina-100911. 


\section{Mongolia as a Transit Nation or "Economic Corridor"}

After 20 years of unsuccessful efforts to find new export customers for its minerals and animal by-products other than its two border neighbors, Mongols of all political persuasions came to recognize that they could not ameliorate the Chinese monopoly over their economy without careful development of real transport and pipeline alternatives to their present poor infrastructure. The Chinese OBOR offers Mongols a way out their trade dilemma only if they are well integrated into the transport grid. Previously, the Mongolian political establishment believed that following World Bank and IMF advice to build new roads and rail spurs south to service the Chinese market would merely perpetuate the dependence on China. Yet as the democratic era entered its third decade, it came to accept that such Chinese gauge infrastructure was necessary in the short-term to keep the economy afloat. Limited financial options, especially on the Russian side, mean that economies of scale and finding less expensive pipe, rail, and road projects can be opportunities for Mongolia to be seen by all parties as an economical "transit corridor" worth developing. However, a longer term strategy of reviving Russian economic investment in Mongolia, building Russian gauge transport infrastructure north to link with the Trans-Siberian rail system, and promoting Mongolia as a reliable and cheaper alternative for Sino-Russian transit traffic within a greater Eurasian transit zone were absolute necessities.

Mongolia has one north-south railroad with Russian gauge-Ulaanbaatar Railways (UR) - and no east-west rail crossing the country. Freight turnover on Ulaanbaatar Railways is growing annually by 2 million tons and is estimated that by 2020 will reach 100 million tons of export cargo. Mongolia wants to build 4 new accesses to China and another 2 accesses to Russia-at investment estimated at around $\$ 1$ billion with over $\$ 400$ million needed to undertake the first stage. ${ }^{46}$ Mongolia's UR network, which is the sole line linking with the Trans-Siberian railroad in the north and China's railroad in the south, is approximately $1,908 \mathrm{~km}$. in total length. The Mongols plan to add an additional $5,600 \mathrm{~km}$. which will increase it four times. The addition of two more rail transit corridors - one for transit between Russia and China and the other enabling internal cargo to move to the two neighbors - will result in a total of three Mongolian transit rail corridors. ${ }^{47}$

In addition to the fact that the railroad plays a vital role in export of coal, minerals, timber, oil, and animal husbandry related products, it also serves

\footnotetext{
46 B. Dulguun, "Yo. Manlaibayar: Mongolia will have three huge transit railroad corridors," $U B$ Post (January 9, 2014).

47 Dulguun, ibid.
} 
as one of the important means of passenger transport. On October 20, 2014 a Memorandum of Understanding for a $\$ 242$ billion high speed rail line project linking Beijing and Moscow through Mongolia was signed by Russia and China. This new passenger train project would reduce the $7000 \mathrm{~km}$. journey from 6 days to $2 .{ }^{48}$ The line would parallel the route of the present UR. A few days later in Mongolia's Parliament a draft bill was approved that permits for the first time Chinese narrow-gauge $(1,435 \mathrm{~mm})$ railroad spurs for transporting raw minerals to coal processing plants across the Chinese border, contingent on agreement on border crossing cooperation between Mongolia and China. Additional Russian wide gauge $(1,520 \mathrm{~mm})$ spurs were approved for several mineral deposits to the Russian border.

The above-mentioned transport projects clearly indicate that Mongolia is now well positioned to profit from exploding Sino-Russian trade, as these neighboring countries expand their transportation cooperation throughout the Eurasian region. Mongolia believes that it can collect substantial transit fees which could be an alternative to falling foreign investment. By increasing its role as a transit corridor in the region, it simultaneously develops its dual rail gauge infrastructure in a more balanced manner so that its products are better able to reach new trade partners. Ultimately this plan could break China's stranglehold on Mongolian trade by helping Japan, South Korea, Southeast Asia, and Vietnam sell their goods as alternatives to Chinese ones to Mongolia, especially if North Korean ports are utilized to avoid Vladivostok congestion. Also, a modernized rail system across Eurasia would permit Turkey, the Middle East, Iran, and Europe to grow their trade with Mongolia in a substantive fashion.

To maximize Mongolia's economic benefits, policymakers have recognized that regional cooperation and integration of transport routes in a Mongolianoriented Transit Corridor is now a necessary national objective. In order to meet the increasing demand for the nation's world-class coal and copper deposits by China and to reach other markets in the region such as in Japan and Korea, Mongolia understands that obtaining FDI and diversification in its economy are dependent upon developing additional transport routes to both Russia and China which allow access to additional seaports. As a result, the newly elected Mongolian People's Party government in 2016 developed a government action plan for 2016-2020 that includes rail, road, and air elements. It also signed a Mongolia-China-Russia Economic Corridor Program. At that time Mongolian Prime Minister J. Erdenebat said: "We are working actively towards solving the

48 John Hutchinson, "Plans unveiled for new £144bn high-speed rail link from Moscow to Beijing that could cut Trans-Siberian journey time by 4 DAYS," dailymail.co.uk (October 17, 2014). 
funds for and realizing the 32 projects reflected in the program. I would like to emphasize on the role of leading nations around the world in establishing the economic corridor between Mongolia, China and Russia which will contribute greatly to regional and global development." ${ }^{\prime 49}$

There remain challenges in connection with creating new transit infrastructure for Mongolia which impede the establishment of the country as a Transit Corridor. 1) Appropriate transit agreements need to be concluded; 2) the domestic railroad and roads system needs to be expanded and modernized; 3 ) border and port infrastructure and transshipment capacities need to be increased; 4) transit tariffs and regulations must be revised; and 5) more financing and significant investment is required for hard infrastructure development. At present, there is priority given to railway facilitation measures, regional rail transport agreements, and rail border crossing procedures. However, there also is progress in negotiating road transport agreements to permit Mongolian, Russian, and Chinese trucks to operate in one another's territories. In Moscow in December 2016 the governments of Mongolia, Russia and China signed an Intergovernmental Agreement on International Road Transport along the Asian Highway Network. ${ }^{50}$

\section{Conclusion}

During a September 2013 mini-conference in Ulaanbaatar of economic experts under the auspices of the World Economic Forum of Davos, Switzerland to discuss the economic challenges facing Mongolia, the danger of Mongolia becoming increasingly reliant on copper and coking coal being exported to only one country, China, was highlighted. Its final report suggested Mongolia must develop development strategies with long lead times. It focused on 3 important concepts: 1) the renaissance in Northeast Asia gives Mongolia the opportunity to sell its main minerals and achieve economic diversification. 2) The "greening" of China to solve its own environmental pollution problems will reduce demand eventually for Mongolian minerals, but should open up new opportunities for Mongolian green products and services. 3) In a region full of geopolitical tensions that impede trade, minerals are used as leverage, so Mongolia should carve out a role as a neutral and respected neighbor as it struggles to access finance and markets and pursue economic diversification. ${ }^{51}$

\footnotetext{
49 The Mongol Messenger, May 19, 2017.

50 "Road transports of Mongolia, Russia and China to be conducted on the Asian Highway routes," The Mongol Messenger (December 16, 2016).

51 "Scenarios for Mongolia" (January 16, 2014), www.weforum.org/issues.
} 
It appears that the Mongolian policymakers have taken the above-mentioned advice very seriously in crafting new foreign economic policy strategy as Eurasian continentalist trends have continued to deepen. In October 2016 Mongolia's newly installed Foreign Minister Tsend Mцnkh-Orgil was asked, "What would be the role and contribution of your Ministry in involving foreign relations in the economic sector or improving the country's economy?" In his reply Mцnkh-Orgil pointed out that the Ministry's participation and contribution are significant in implementing bilateral and multilateral measures directed to expanding foreign trade and economics, creating a favorable environment for investors and entrepreneurs, and inspiring their confidence in Mongolia's legal regime. He particularly noted that Mongolia's top foreign policy priorities are continuing dialogue on the creation of an "Economic Corridor," actively participating in regional integration, joining the U.S.-Asia Pacific Trade Agreement and WTO Trade Facilitation Agreement, promoting business, and improving the investment environment for investors. ${ }^{52}$

Mongolia historically viewed its landlocked position on the Eurasian continent as a national security plus and developed political and economic mechanisms to play its two border neighbors against each other. This strategy, while in many respects essential to ensure cultural and national independence, resigned the population to poverty and a reactive foreign policy. During the past decade, Mongolia has recognized that, if it is to attain maximum economic benefit from its rich mineral resources and not be marginalized politically by Russia and China as happened in past centuries, it needs to proactively take positive advantage of its geographical position to become a significant and cost effective transit link via rail, road, and pipe between the two giant economies. In the mid-2000s, Mongolia's neighbors had rejected Mongolia's idea of being a "transit corridor" linking the Chinese and Russian economies. Ten years later, landlocked, sparsely populated and resource-rich Mongolia's geostrategic position serves as a less expensive conduit into the Northeast and Central Asian regions for both Russia and China, who now agree that Mongolia can be an "Economic Corridor" in the region.

A vibrant "Third Neighbor" foreign policy continues to be the foundation to Mongolia's future - politically and economically — and indicates Mongolia's commitment to democracy remains strong. However, it is the manner of implementation of the "Third Neighbor Policy," which is the cornerstone of its modern foreign relations strategy that will determine whether Mongolia "remains a minor, local nation or sets out to become a full member of the

\footnotetext{
52 "Our weight depends on how many friend we have got," The Mongol Messenger (October 21,
} 2016). 
global community." ${ }^{33}$ Concerns over sovereignty and control also are connected to Mongolia's reconfigurating its list of "Third Neighbors" and its new trilateralism mechanisms.

The Mongolian "Asian Wolf" overall plan is to revise and develop mineral agreements to demand that foreign investors finance power plants, mineral processing industries to produce value-added products, and domestic rail and road transport infrastructure. Yet, the fear remains that Chinese and Russian construction projects will make transport of Mongolia's mineral exports even more dependent on the two countries. While Russia's status as Mongolia's traditional "big brother" is significant, the emergence of China in Mongolia's energy sector and major FDI partner is increasingly viewed as a way to break Russia's energy monopoly. Although Mongolia's close proximity to China, the world's largest coal importer, and high-quality coal grades will help Mongolia maintain its position as a leading supplier, declining Chinese demand in future decades will substantially reduce revenues. Since this trend will continue, Mongolia increasingly will need to look to other markets for its minerals, especially coal. Mongols expect the growth of domestic mineral production to fall in the near term; however, they are confident they will receive increased revenue from diversifying exports to fewer higher-value products. But the key for Mongolia is to solve the lack of modern transport infrastructure which cripples its potential trade partners. Mongolia will ask Japan and both Koreas to partner with Russia in building pipelines and expanding rail routes north to the Pacific to enable Mongolia to develop access to new customers and decrease reliance on the south-to-China transport route.

In 2017 Mongolia has experienced a rebound in its coal exports. China's ban on North Korean coal imports boosted demand for Mongolian coking coal for its steel production. ${ }^{54}$ However, Mongolia is planning on more than temporary sanctions to increase markets for its mineral exports. It recognizes that while its sales of coal have recovered, infrastructure constraints, especially lack of rail capacity, continues to cause 'bottlenecks' and delays in getting Mongolian products to markets. It is counting on linking into China's 'One Belt, One Road' (OBOR) "to improve access to existing markets in China and Russia and enter new ones as far afield as Eastern Europe." 55

53 Ikeda Norihiko, "Mongolia: Will it remain a Local Buffer Nation between China and Russia, or Become a Small Yet Global Nation? A new perspective on the "Third Neighbor Policy," The Mongol Messenger (October 28, 2016).

54 According to Thomas Hugger, founder and CEO of Asia Frontier Capital. See Sri Jegarajah, "Mongolian coal miners bet on One Belt, One Road to feed demand" (February 22, 2017), http://www.cnbc.com/2017/02/22/mongolian-coal-miners-bet-on-one-belt-one-road-to-feeddemand.html.

55 David Paull, managing director of ASX-listed Aspire Mining Ltd., interviewed in $\underline{\text { Sri }}$ 
The main trends in Mongolian foreign and economic relations that are reflections of the emerging continental dynamism are epitomized in four distinct strategies: 1) Evolving "Third Neighbor" policy. 2) Trilateralism. 3) Economic Diversification and Industrial Zones. 4) "Transit Nation" or "Economic Corridor." These were all developed during the Elbegdorj era, but are likely to be continued by his successor's government so that Mongolia can integrate more effectively into Eurasia's "Silk Road" development paradigm. 